\title{
Scalp blok untuk Kraniotomi dan Penanganan Nyeri Membandel Pasca Kraniotomi
}

\author{
Sri Rahardjo, Mahmud \\ Departemen Anestesiologi \& Terapi Intensif Fakultas Kedokteran Universitas Gajah Mada-RSUP Dr. Sardjito \\ Yogjakarta
}

\begin{abstract}
Abstrak
Pemberian anestesi lokal dari saraf kulit kepala disebut sebagai "Scalp block". Teknik ini telah diperkenalkan beberapa abad lalu, sempat tidak popular kemudian popular kembali pada era anestesi modern dalam manajemen anestesi intra operatif dan post operatif. Indonesia telah memasuki era pelayanan kesehatan dengan universal health coverage melalui Badan Penyelenggara Jaminan Sosial (BPJS), menyebabkan pemberi layanan anestesi harus familiar dengan prinsip dasar ekonomi medis dan ikut berperan aktif dalam mengendalikan biaya untuk tata kelola anestesi. Pelayanan anestesi memiliki banyak kesempatan mengendalikan biaya, tentu saja dengan tetap menjaga keseimbangan antara keselamatan dan pembiayaan pasien. "Scalp block" adalah salah satu teknik pilihan yang dapat dikombinasikan dengan pembiusan umum. Disini akan ditinjau penggunaan "Scalp block" untuk operasi kraniotomi dan penanganan nyeri membandel pasca kraniotomi dengan dasar anatomi, evolusi histori, teknik yang berkembang saat ini, potensi keuntungan dan kekurangannya. Kami mendukung penggunaan teknik ini untuk penggunaan secara luas pada masa depan
\end{abstract}

Kata kunci: Kraniotomi; scalp block; anestesi

JNI 2020; 9 (1): 51-59

\section{"Scalp Block" for Craniotomy and Intractable Pain Management Post Craniotomy}

\begin{abstract}
Using local anesthesia of the nerves of the scalp is referred as "scalp block." This technique was introduced more than a century ago, but has undergone a modern rebirth in intraoperatif and postoperative anesthetic management. Indonesia has entered the era of health services which universal health coverage BPJS (Heath Social Organizing Agency), this causes the provider to be familiar with the basic principles of medical economics and participate actively in controlling costs for anesthesia service. Providers of anesthesia services have many opportunities to reduce these costs, with the aim of maintaining balance between profit, patient safety and costs. Scalp block is an alternative option that can be combined with general anesthesia. Here, we review the use of "scalp block" during craniotomy and refractory post craniotomy pain with its anatomic basis, historical evolution, current technique, potential advantages, and pitfalls. We also address its current and potential future applications
\end{abstract}

Key words: Craniotomy; scalp block, anesthesia

JNI 2020; 9 (1): 51-59 


\section{Pendahuluan}

Prinsip "Scalp block" adalah memblok serabut saraf tepi pada kulit kepala, teknik ini dikembangkan pada awal 1900-an oleh Harvey Cushing, dan George Crile. ${ }^{1}$ Blok area insisi operasi pada kulit kepala dapat dilengkapi dengan blok pada saraf yang mempersarafi kulit daerah tersebut. Blok ini dapat dilakukan pada saraf supra orbital, supra trochlea, zygomaticum temporal, auriculo temporal, auricular mayor, greater oksipital dan lesser occipital. Perkembangan dari teknik ini dibatasi oleh ketersedian obat anestesi lokal yang ada. Anestesi lokal kokain yang ada bersifat adiktif, kardiotoksik dan neurotoksik, sedang prokain obat anestesi lokal yang mempunyai lama kerja pendek dan mempunyai frekwensi allergi yang tinggi. Heinrick Braun, melakukan penambahan epinefrin pada anestesi lokal sehingga memiliki manfaat memperpanjang lama kerja dan mengurangi perdarahan daerah operasi. ${ }^{1,2}$ Scalp block awalnya dilakukan untuk prosedur operasi intrakranial tanpa perlu anestesi umum. Dengan diperkenalkannya pipa endotrakeal dan perkembangan anestesi umum, penggunaan scalp block mulai jarang dilakukan. Namun scalp block masih dibutuhkan untuk pembedahan kepala dengan prosedur tertentu yaitu saat dibutuhkan kesadaran pasien, atau teknik yang memerlukan penilaian fungsional pasien, kraniotomi, deep brain stimulation, prosedur stereotactic, serta pengobatan chronic pain syndromes dari kepala dan leher. ${ }^{2}$

Penelitian meta analisis pada 320 pasien menunjukan penggunaan teknik scalp block menumpulkan respon hemodinamik saat pemasangan head pin, mengurangi nyeri pascaoperasi, mengurangi kebutuhan opioid sehingga memudahkan penilaian neurologi pascaoperasi. ${ }^{2}$ Dengan tersedianya obat anestesi lokal yang mempunyai lama kerja panjang, serta perkembangan dari teknik scalp block sendiri dari yang semula memblok area insisi operasi pada kulit kepala dengan infiltrasi anestesi lokal, menjadi teknik lebih selektif yaitu dengan memblok serabut saraf yang mempersarafi area insisi pada kulit kepala, hal ini membuka kesempatan yang lebih luas dalam penggunaan teknik Scalp block ini. ${ }^{1-3}$

\section{Indikasi dan Kontra Indikasi}

Scalp block dapat dilakukan untuk semua prosedur intrakranial supratentorial, serta dapat meminimalkan respons hemodinamik terhadap stimulus pembedahan, mengurangi kebutuhan obat anestesi intraoperatif, mengurangi nyeri pascaoperasi dan menurunnya konsumsi analgesi morfin. Meskipun dapat memberikan anestesi yang efektif untuk sayatan kulit dan kraniotomi, tetapi tidak memberikan anestesi pada duramater. Seperti pada "Awake craniotomy" pada scalp block penggunaan analgesi intravena masih diperlukan untuk kenyamanan pasien yang diberikan secara titrasi untuk melakukan penilaian fungsi. Scalp block juga dapat dipergunakan untuk pembedahan lain dikepala pada kasus kasus dermatologi termasuk keratosis, karsinoma dan juga kranioplasty. ${ }^{2,4}$

Hal yang penting pada scalp block adalah blok serabut saraf oksipital mayor atau great oksipital nerve $(\mathrm{GON})$. Teknik ini telah digunakan di klinik sakit kepala selama beberapa dekade untuk menangani pasien dengan neuralgia oksipital, migrain, cluster headache, dan sakit kepala pascakontusio. Seperti GON, serabut saraf third occipital nerve (TON) dapat merupakan generator pain untuk chepalgia terutama setelah whip plash injury pada persendian zygophyseal C2-3. Serabut saraf oksipital ketiga mempunyai serabut kutaneus yang mempersarafi bagian bawah kepala. ${ }^{2,4}$

\section{Kontraindikasi}

Kontraindikasi penggunaan teknik scalp block ini sangat jarang, namun bagi individu yang alergi terhadap anestesi lokal teknik ini dikontraindikasikan demikian juga untuk dihindari injeksi anestesi lokal pada daerah yang mengalami infeksi. ${ }^{3,4}$

\section{Keuntungan Scalp block}

Penelitian meta-analisis pada teknik scalp block yang dilakukan dengan membandingkan waktu 
pemberiaan antara pemberian preoperasi sebelum sayatan kulit dengan pemberian pascaoperasi saat penutupan kulit, kesemuanya menurunkan nilai skor nyeri pada 1 jam post operasi (mean difference: $1,6,95 \%$ Confidence interval: $\mathrm{P}<0,001$ ), penurunan nilai skor nyeri sampai 8 jam pada pemberian preoperasi sebelum sayatan kulit dan sampai 12 jam pada pemberian pasca operasi saat penutupan kulit. Hasil lain penelitian penggunaan scalp block akan menurunkan penggunaan kosumsi obat analgesi morfin. ${ }^{4}$

Beberapa penelitian dengan menggunakan teknik scalp block memberikan hasil penurunan skor nyeri segera secara siknifikan yang dinilai ketika pasien di post anesthetic care unit (PACU) dan sampai satu jam setelah pemberian. Penelitian teknik scalp block dengan menggunakan ropivacain $0,75 \%$ atau bupivacain $0,5 \%$, pada saat sebelum penjahitan kulit dan saat penutupan kulit memberikan hasil yang sama, kedua lokal anestesi tersebut menurunkan kebutuhan morfin pada periode post operasi, sedang pada yang menggunakan ropivacaine $0,75 \%$ memberikan hasil yang juga menurunkan nyeri segera pada periode post operasi. Penelitian dengan menggunakan campuran lidokain dan ropivacaine pada pre maupun post operasi yang diberikan sebelum sayatan kulit memberikan hasil menurunkan nyeri post operasi serta menurunkan kebutuhan morfin. Hal ini mendukung teori "preemptive analgesia", bahwa lokal anestesi akan menghambat "pain-signal transmission". ${ }^{2}$

Penelitian untuk menangani nyeri kronik pascacraniotomy dilakukan dengan memberi lokal infiltrasi ropivacain memberikan hasil yang siknifikan menurunkan nyeri persisten sampai 2 bulan setelah kraniotomi. Untuk infratentorial tumor secara random penggunanaan scalp block memberikan hasil menumpulkan respon hemodinamik dan menurunkan kebutuhan morfin saat pemasangan head pin. ${ }^{4}$

\section{Teknik}

Girvin 1986 memperkenalkan teknik scalp block ini untuk awake kraniotomi selama operasi intrakranial. Prosedur dilakukan dengan memblok divisi V1 (supratrochlear dan supraorbital nerves), divisi V2 (zygomatico temporal nerve), divisi V3 (auriculotemporal nerve) dari saraf kranial ke $\mathrm{V}$ (saraf trigeminus), serta cabang dari cervical $\mathrm{C} 2$ dan $\mathrm{C} 3$ (cabang posterior dari saraf great auricular nerve, lesser occipital nerve), greater occipital nerve (GON), dan third oksipital nerves (TON). Teknik scalp block dapat digunakan sebagai tambahan pada anestesia umum ataupun digunakan secara tunggal pada pembedahan intra-ekstrakranial.

Keberhasilan dari teknik ini memerlukan blok beberapa serabut saraf yang dilakukan pada satu atau lebih serabut saraf baik untuk diagnostik atau pengobatan sakit kepala kronis. Scalp block dapat dilakukan secara unilateral ataupun bilateral sebelum pemasangan head pin. Penyuntikan obat anestesi lokal pada scalp block dapat dilakukan pada beberapa titik. Diperlukan pemahaman anatomi dalam mencapai keberhasilan teknik ini. Kondisi banyaknya vaskularisasi dikulit kepala, penggunaan volume yang besar ataupun adanya kelainan tulang kepala memerlukan perhatian kusus, perlu diperhatikan adanya toksisitas sistemik, kardiotoksik ataupun neurotoksik pada pemberian obat anestesi lokal terutama obat yang memiliki onset lambat. Untuk blok pada daerah supraorbita dan sebagian daerah frontal dapat diberikan suntikan pada saraf supratrochlear dan saraf supraorbital. Penyuntikan anestesi lokal pada saraf supratroklear dilakukan pada $1,6 \mathrm{~cm}$ lateral garis tengah, $0,7 \mathrm{~cm}$ tepi bawah orbital superior atau alis mata dengan volume $1-2 \mathrm{ml}$ anestesi lokal untuk setiap saraf supratrochlear. Penyuntikan anestesi lokal pada saraf supraorbital dilakukan pada $1 \mathrm{~cm}$ sebelah lateral dari saraf supratrochlear dengan 1-2 $\mathrm{ml}$ anestesi lokal untuk setiap saraf supraorbita menggunakan jarum ukuran 23 atau 25-gauge yang disuntikkan tegak lurus dengan kulit alis mata. ${ }^{5-7}$

Untuk daerah antara frontal dan temporal dapat disuntikkan di daerah saraf zigomaticotemporal yang merupakan divisi V2 dari saraf kranial ke 5 (saraf trigeminus). Penyuntikan obat lokal anestesi dilakukan $1 \mathrm{~cm}$ postero lateral canthus dengan volume 2-3 ml. ${ }^{5,7}$ Anestesi daerah temporal dapat disuntikkan obat anestesi lokal didaerah serabut saraf aurikulotemporal yang merupakan divisi 
V3 dari saraf kranial ke 5 (saraf trigeminus). Daerah suntikan 1,5 cm anterior tragus. Beberapa teknik menyarankan penyuntikan sampai daerah fasia dalam, tetapi penyuntikan yang superfisial sudah memadai untuk mendapatkan blok tersebut sehingga penyuntikan sampai fasia dalam tidak diperlukan berkaitan dengan risiko terjadinya blok saraf fasialis. Untuk daerah oksipital dan sebagian temporal posterior dapat disuntikkan disuntikan pada daerah tragus kurang lebihnya $1,5 \mathrm{~cm}$ didepan telinga, serabut saraf postauricular; $3 \mathrm{ml}$ larutan anestesi lokal disuntikan pada daerah tragus kurang lebihnya $1,5 \mathrm{~cm}$ dibelakang telinga, blok pada daerah ini tidak mutlak diperlukan karena hanya menghilangkan sensori minimal pembedahan daerah mastoid. (acoustic neuroma resection, terutama pendekatan translabyrint). Saraf greater occipital, lesser occipital; Saraf
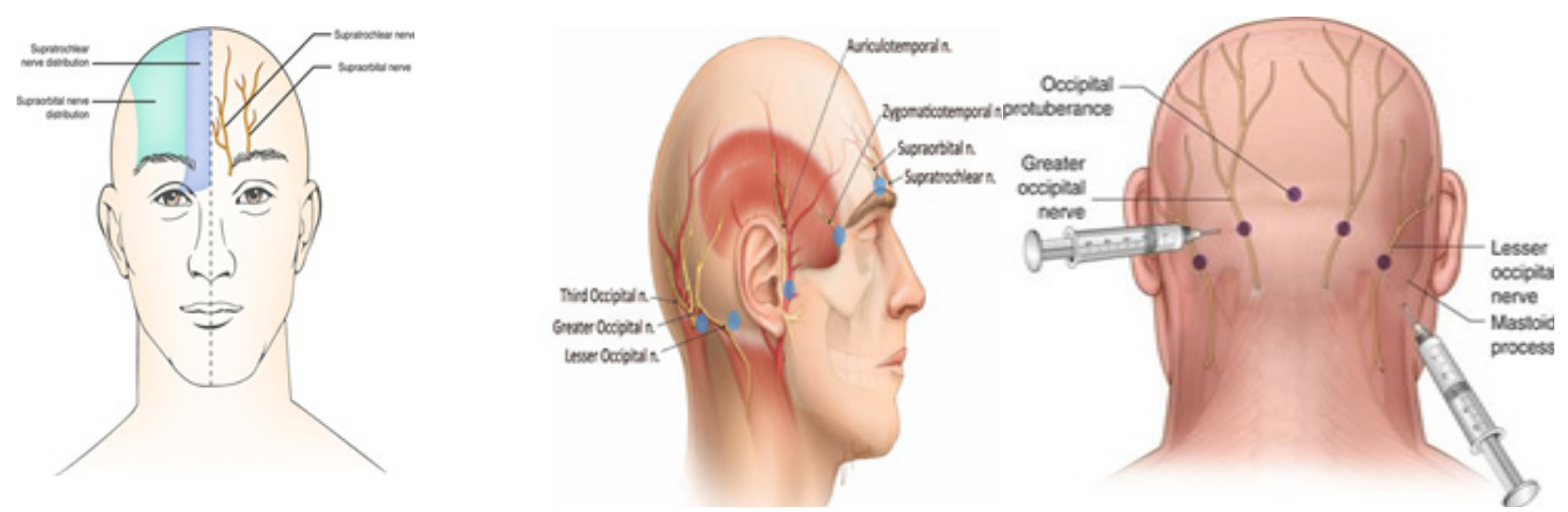

Gambar 1. Anatomi Scalp block ${ }^{4-6}$

obat anestesi lokal pada lesser oksipital nerve dan greater occpital nerve (GON), third oksipital nerve (TON) yang merupakan cabang dari Cervical 2 dan Cervical 3. ${ }^{5-7}$

Obat anestesi lokal yang dapat diberikan adalah lidokain, bupivacain, levobupivacain, ropivacain dengan konsentrasi $0,2 \%, 0,375 \%$ sampai $1 \%$ karena hanya untuk sensory block sebanyak 2-3 cc pada setiap serabut saraf yang dapat ditambah epinefrin $1 / 200.000$, penambahan epinefrin ini dimaksudkan untuk menambah lama kerja obat anestesi lokal dan megurangi perdarahan saat menyayat scalp. Dosis bupivakain-epinefrin total yang aman adalah $1,5 \mathrm{mg} / \mathrm{kg}$. Umumnya bisa digunakan $50 \mathrm{ml}$ bupivakain $0,25 \%+$ epinefrin $1 / 200.000$. Harus diingat mula kerja obat anestesi lokal mulai saat menyuntikan obat anestesi lokal pada daerah yang akan dipasang head pin..$^{5-8}$

Tempat-tempat penyuntikan obat anestesi lokal sebagai berikut: serabut saraf supraorbital dan supratrochlear; 1-2 $\mathrm{ml}$ larutan anestesi lokal disuntikan pada daerah diatas alis mata, serabut saraf auriculotemporal; $2 \mathrm{ml}$ larutan anestesi lokal greater occipital; 3-5 $\mathrm{ml}$ larutan anestesi lokal disuntikan pada sepertiga lateral pada daerah garis maya superior nuchal line yang dibentuk antara prutuberansia oksipitalis kearah prosessus mastoideus. $^{5-7}$ Sepertiga lateral dari tempat penyuntikan saraf greater oksipital merupakan tempat penyuntikan dari saraf lesser occipital. Diperkirakan tempat penyuntikan dari saraf saraf tersebut pada garis maya superior nuchal berjarak 4 dan $7 \mathrm{~cm}$ dari protuberansia occipital, saraf oksipital ketiga terletak $3 \mathrm{~mm}$ (rata-rata, 0-4 mm) lateral dari protuberansia oksipital eksternal dan berkomunikasi dengan saraf greater oksipital disebelah lateralnya. Saraf ini mempersarafi bagian posterior aspek posterior kepala. Distribusi dari saraf ini merupakan hal penting untuk mengilangkan nyeri saat sayatan pada sebagian besar pembedahan supratentorial, sedang untuk pembedahan infratentorial diperlukan dosis tambahan blok saraf yang dapat diberikan penyuntikan subcutaneous pada $6 \mathrm{~cm}$ dibawah protuberansia oksipitalis eksterna dan sedikit lateral dari garis tengah. Pada sakit kepala kronis blok pada saraf oksipital ketiga dilakukan pada akar saraf dibawah panduan flouroscopik 
atau ultrasound. Untuk mengurangi nyeri pada pemasangan head spin dapat dilakukan penyuntikan pada daerah pemasangan dengan anestesi lokal yang dikombinasi dengan teknik scalp block yang dapat menghilangkan nyeri sampai 48 jam pascaoperasi.

Duramater mendapat inervasi yang sama dari saraf kranialis dan saraf spinal seperti pada daerah persarafan ekstrakranial, ini penting terhadap stress karena persarafan pada duramater sangatlah komplek dan kurang dipengaruhi oleh blok saraf ini, ini yang mendasari pada awake craniotomy saat pembukaan duramater akan berespon dan pasien memerlukan tambahan obat analgesi intravena. Lebih lanjut robekan, inflamasi duramater akan menyebabkan postoperative cephalgia walaupun scalp block efektif. Nyeri yang berasal dari intrakranial berkaitan dengan distribusi saraf somatiknya, secara umum akan mengikuti perjalanan dari arteri-vena. Jika diperlukan dapat disuntikan secara hati hati anestesi lokal diantara duramater dengan berpedoman perjalanan arteri-vena yang sesuai daerah duramater., ${ }^{2,-6}$

\section{Monitoring}

Monitoring dilakukan seperti pada tindakan operasi bedah saraf pada umumnya dengan lebih ditekankan terhadap efek kardiotoksik, neurotoksik, alergi terhadap obat anestesi lokal serta adanya toksisitas sistimik dari obat anestesi lokal. ${ }^{5,6,7}$

\section{Risiko}

Seperti pada umumnya toksisitas penggunaan anestesi lokal dapat disebabkan karena penyerapan sistimik, penyuntikan intravaskuler langsung, adanya shunting atau pemberian yang tidak sengaja masuk pada tempat tertentu seperti pada defek tulang kepala harus dipertimbangkan. Konsentrasi plasma anestesi lokal akan segera meningkat sesuai dengan banyaknya vaskularisasi daerah kepala dibanding teknik neuronal blok lain, sehingga tanda toksik anestesi lokal dapat segera terlihat pada 15 menit pertama setelah penyuntikan (absorption-related toxicity) walau hal ini jarang terjadi. ${ }^{2}$ Toksisitas anestesi lokal ini dapat terlihat sebagai kejang, ketidak stabilan hemodinamik penyebab henti jantung atau sampai hilangnya kesadaran. Harus dipertimbangkan potensi kerusakan saraf pada injeksi intraneural akibat tekanan saat pemberian obat anestesi lokal. ${ }^{2}$ Bupivacain, ropivacain, dan levobupivacain adalah anestesi lokal kerja panjang untuk scalp block. Ropivacain dan levobupivacain mempunyai profil yang lebih baik serta therapeutic window yang lebih luas dibanding bupivacain, dosis rendah bupivacain dapat menimbulkan kardiovascular dan neurotoksisitas dibanding ropivacain, dan levobupivacain. Anestesi lokal Lidokain tunggal jarang digunakan untuk scalp block karena lama kerja yang pendek, namun mula kerja yang cepat bermanfaat untuk nyeri dura atau selama pemasangan peralatan selama awake craniotomy, beberapa ahli melakukan kombinasi lidokain dengan bupivacain atau ropivacain untuk mendapatkan mula kerja yang cepat serta lama kerja yang panjang. Konsentrasi anestesi lokal penting menjadi ukuran untuk menghilangkan nyeri akut pascaoperasi tetapi penambahan epineprin mempunyai hasil yang berbeda dalam peningkatan kadar plasma, lama kerja anestesi lokal dan toksisitas yang terjadi.

Osborn dan Sebeo; potensial komplikasi scalp block adalah masuknya ke intra-arterial menyebabkan aliran retrograde kedalam a. karotis internal dengan akibat henti nafas, hematoma serta potensi infeksi, serta adanya kelumpuhan permanen saraf fasialis yang tidak pernah dilaporkan dalam beberapa literatur yang dapat terjadi pada penyuntikan saraf zygomaticotemporal dan auriculotemporal walau umumnya bersifat sementara karena letaknya yang superfisial.2,7,9,10 Secara keseluruhan scalp block merupakan teknik yang aman bila dilakukan dengan teknik yang benar serta memahami kedudukan anatominya. Selama perioperasi kadang memerlukan pencitraan ataupun perubahan posisi yang potensial merubah penyebaran anestesi lokal, karena hal tersebut sebaiknya scalp block dilakukan setelah posisi, lokasi dan fiksasi dari prosedur pembedahan sudah pasti. ${ }^{7,9,10}$ 


\section{Pengaruh Scalp block}

\section{Terhadap Hemodinamik}

Pada pembedahan tumor intrakranial, scalp block bertujuan mencegah terjadinya perubahan hemodinamik saat sayatan kulit kepala. Potensi morbiditas yang terjadi dengan adanya perubahan hemodinamik akibat stres respon seperti meningkatnya tekanan darah dan laju jantung yang berefek meningkatnya jumlah aliran darah ke otak (ADO) yang meningkatkan tekanan intrakranial (TIK). ${ }^{2,12,13}$

Beberapa penelitiaan menyebutkan kegunaan scalp block dapat memberikan anestesi pada bagian kulit, jaringan subkutis, otot, daerah periosteum ekternal tulang kepala. Bagian periosteuminternal dan duramater tidak teranestesi dengan baik, hal ini terjadi karena bagian ini dipersarafi saraf dari pembuluh darah meningeal.
Namun bagian ini dianggap tidak terlalu sensitif. Penelitian menyebutkan scalp block dengan $0,5 \%$ bupivakain menunjukan stabilitas laju denyut jantung selama operasi, dan juga menunjukan tidak ada perubahan bermakna pada aliran darah otak (ADO) saat sayatan kulit kepala. ${ }^{2,12,13}$ Efektifitas scalp block kulit sebagai teknik yang berdiri sendiri untuk prosedur intrakranial dari fossa kranial anterior dan fossa kranial medial mulai diakui selama perioperasi (pemasangan head pin, selamasetelah operasi serta penanganan nyeri post operasi). Penelitian terbaru menunjukkan ketika scalp block digunakan sebagai tambahan untuk anestesi umum menunjukan hasil hemodinamik yang baik, dan penggunaan teknik scalp block pada daerah pembedahan dengan anestesi lokal dapat meningkatkan analgesia pascaoperasi. ${ }^{2,12,13}$

Tabel 1. Penelitian RCT dari scalp block dan infiltasi anestesi lokal terhadap respon hemodinamik selama dan setelah pembedahan intrakranial. ${ }^{2}$

\begin{tabular}{|c|c|c|c|c|}
\hline Study & $\begin{array}{l}\text { Surgery } \\
\text { type }\end{array}$ & Intervention (pts per group) & Timing & Findings \\
\hline $\begin{array}{l}\text { Bloomfeld et } \\
\text { al [29] }\end{array}$ & Supratent & $\begin{array}{l}\text { Infiltration: } 0.25 \% \text { bupiv/ } 1: 200 \mathrm{~K} \text { epinephr } \\
\text { vs saline } 1: 200 \mathrm{~K} \text { epinephr ( } 18 \mathrm{pts} / \text { group). } \\
\text { Pin sites injected before fixation }\end{array}$ & $\begin{array}{l}\text { Preincis \& } \\
\text { postsurg }\end{array}$ & $\begin{array}{l}\text { HR higher in saline group at dural \& skin } \\
\text { closure. No effect on postop hemody- } \\
\text { namics. VAS lower in the bupiv group at } \\
\text { PACU admission but NS }(\mathrm{P}=0.06) \text { at } 1 \mathrm{hr}\end{array}$ \\
\hline $\begin{array}{l}\text { EL-Dawlatly } \\
\text { et al [28] }\end{array}$ & Supratent & $\begin{array}{l}\text { Infiltration of pin insertion sites: } 0.25 \% \\
\text { bupiv vs saline }\end{array}$ & $\begin{array}{l}\text { Preincis pre- } \\
\text { pin placement }\end{array}$ & $\begin{array}{l}\text { VAS lower at } 2,4,36,48 \mathrm{hrs} \text {. No diffs in } \\
\text { hemodynamic parameters }\end{array}$ \\
\hline $\begin{array}{l}\text { Geze et al } \\
{[50]}\end{array}$ & Intracranl & $\begin{array}{l}\text { 1) Scalp block w } / 0.5 \% \text { bupiv, } 2 \text { ) infiltra- } \\
\text { tion at pin insertion sites with } 0.5 \% \text { bupiv } \\
\text { vs } 3 \text { ) IV opioid analgesics (controls). }\end{array}$ & Preincis & $\begin{array}{l}\text { Sacalp block blunted hemodynamic } \\
\text { response to pinning vs other } 2 \text { groups. }\end{array}$ \\
\hline Lee at al [49] & Supratent & $\begin{array}{l}\text { Scalp block: } 0.25 \% \text { bupiv vs saline } \\
\text { controls. }\end{array}$ & Preincis & $\begin{array}{l}20 \% \text { increase in HR or MAP triggered } \\
\text { intervention: } 2.5 \mathrm{mg} / \mathrm{kg} \text { thiopental \& } 2 \mu / \\
\mathrm{kg} \text { fentanyl. Two of } 8 \mathrm{pts} \text { in scalp block } \\
\text { group \& } 8 \text { of } 8 \text { control group pts required } \\
\text { the intervention. }\end{array}$ \\
\hline $\begin{array}{l}\text { Mohammadi } \\
\text { et al [51] }\end{array}$ & Intracranl & $\begin{array}{l}\text { Infiltration: } 0.25 \% \text { bupiv vs saline } \\
\text { controls. }\end{array}$ & Preincis & $\begin{array}{l}\text { Decrease in average MAP, HR from inci- } \\
\text { sion to dural opening in bupiv group. }\end{array}$ \\
\hline $\begin{array}{l}\text { Pinosky et } \\
\text { al [3] }\end{array}$ & Intracranl & $\begin{array}{l}\text { Saclp block: } 0.5 \% \text { bupiv vs saline controls } \\
\text { given } 5 \text { min before cranial fixation. }\end{array}$ & Preincis & $\begin{array}{l}\text { With cranial fixation, significant increases } \\
\text { noted in SBP } 40 \pm 6 \mathrm{mmHg} \text {, DBP } 30 \pm 5 \\
\mathrm{mmHg} \text {, MAP } 32 \pm 6 \mathrm{mmHg} \text {, and HR } 22 \pm 5 \\
\text { bpm in controls; no changes in bupiv } \\
\text { group. }\end{array}$ \\
\hline \multicolumn{5}{|c|}{$\begin{array}{l}\text { Supreatent=supratentorial. bupiv=bupivacaine, preincis=preincision, preincisional, } \mathrm{HR}=\text { heart rate, epinephr=epinephr, } \\
\text { postsurg=postsurgery, postsurgical, postop=postoperative, } \mathrm{VAS}=\text { visual analog scale, } \mathrm{PACU}=\text { postanesthesia Care Unit, } \\
\mathrm{NS}=\text { nonsignificant, pre-pin=before pin insertion, diffs=differences, intracranl=intracranial, IV=intravenous, pediatr=pediatric, } \\
\mathrm{MAP}=\text { mean arterial pressure, } \mathrm{SBP}=\text { systolic blood pressure, } \mathrm{DPB}=\text { diastolic blood pressure }\end{array}$} \\
\hline
\end{tabular}




\section{Tabel 2. Pengaruh Scalp block, infiltrasi anestesi lokal dan blok pleksus cervikalis superfisial pada nyeri} post operasi pembedahan intrakranial. ${ }^{2}$

\begin{tabular}{|c|c|c|c|c|c|}
\hline Study & $\begin{array}{l}\text { Surgery } \\
\text { type }\end{array}$ & $\begin{array}{l}\text { Study } \\
\text { type }\end{array}$ & intervention (pts per group) & Timing & Finding \\
\hline \multicolumn{6}{|l|}{ Acute pain } \\
\hline $\begin{array}{l}\text { Ayoub et al } \\
{[43]}\end{array}$ & Supratent & $\mathrm{RCT}$ & $\begin{array}{l}\text { Remifent-based GA. } 0.1 \mathrm{mg} / \mathrm{kg} \text { morphine } \\
\text { sulfate or scalp block w/20 mL 50:50 0.5\% } \\
\text { bupiv \& } 2 \% \text { lidocain; saline controls used in } \\
\text { each } 25 \text {-pt group }\end{array}$ & Postsurg & $\begin{array}{l}\text { Pain scores, time to } 1 \text { st request for } \\
\text { analgesia, total SQ codeine use similiar } \\
\text { in both groups in } 24-\mathrm{hr} \text { study pd. }\end{array}$ \\
\hline Bala et al [4] & Supratent & $\mathrm{RCT}$ & $\begin{array}{l}\text { Scalp block: } 0.5 \% \text { bupiv/1:400K epinphr vs } \\
\text { saline controls ( } 20 \mathrm{pts} / \text { group) }\end{array}$ & Postsurg & $\begin{array}{l}\text { Decreased pain, less need for rescue } \\
\text { med in intervention group in 1st } 6 \mathrm{hrs} \text { of } \\
\text { 12-hr observ pd }\end{array}$ \\
\hline Batoz et al [61] & Intracranl & $\mathrm{RCT}$ & $\begin{array}{l}\text { Infiltration: } 20 \mathrm{~mL} 0.75 \% \text { ropiv }(\mathrm{n}=25) \mathrm{vs} \text { no } \\
\text { infiltration }(\mathrm{n}=27)\end{array}$ & Postsurg & $\begin{array}{l}\text { Decreased pain, trend to less opioid use } \\
\text { in intervention group 1st } 24 \text { hrs after } \\
\text { surgery (see Chronic pain below) }\end{array}$ \\
\hline $\begin{array}{l}\text { Biswas \& } \\
\text { Bithal [62] }\end{array}$ & Supratent & $\mathrm{RCT}$ & $\begin{array}{l}\text { Infiltration: } 25 \mathrm{~mL} 0.25 \% \text { bupiv }+ \text { IV saline } \\
\text { vs } 25 \mathrm{~mL} \text { saline }+2 \mu \mathrm{g} / \mathrm{kg} \text { fentanyl } 5 \mathrm{~min} \\
\text { preincis }\end{array}$ & Preincis & $\begin{array}{l}\text { No diffs in } \mathrm{n} / \mathrm{pts} \text { needing rescue in } 1 \mathrm{st} \\
12 \text { hrs. upiv delayed rescue a median } \\
105 \text { vs } 60 \text { min in fentanyl group }\end{array}$ \\
\hline $\begin{array}{l}\text { Bloomfeld et } \\
\text { al [29] }\end{array}$ & Supratent & $\mathrm{RCT}$ & $\begin{array}{l}\text { Infiltration: } 25 \mathrm{~mL} 0.25 \% \text { bupiv/ } 1: 200 \mathrm{~K} \\
\text { epinephr vs saline/ } 1: 200 \mathrm{~K} \text { epinephr }(18 \mathrm{pts} \text { / } \\
\text { group). Pin sites injected before fixation. }\end{array}$ & $\begin{array}{l}\text { Preincis \& } \\
\text { Postsurg }\end{array}$ & $\begin{array}{l}\text { Pain on PACU admission less in bupiv } \\
\text { group. No diffs at } 1 \mathrm{hr}(\mathrm{p}=0.06)\end{array}$ \\
\hline $\begin{array}{l}\text { Gazoni et al } \\
{[53]}\end{array}$ & Supratent & $\mathrm{RCT}$ & $\begin{array}{l}\text { Remifent-based GA. Scalp block: } 0.5 \% \text { ropiv } \\
(\mathrm{n}=14) \text { vs np block }(\mathrm{n}=16)\end{array}$ & Preincis & $\begin{array}{l}\text { Pain less in intervention group in } 1 \text { st } 4 \\
\text { postop hrs. Trend to less opioid use in } \\
1 \text { st } 24 \mathrm{hrs} \text { postop }\end{array}$ \\
\hline $\begin{array}{l}\text { Girard et al } \\
{[30]}\end{array}$ & $\begin{array}{l}\text { Infratent \& } \\
\text { occipital }\end{array}$ & $\mathrm{RCT}$ & $\begin{array}{l}\text { Remifent-based GA. Bilat superficial cervical } \\
\text { plexus block: } 20 \mathrm{~mL} 50: 500.5 \% \text { bupiv \& } 2 \% \\
\text { lidocaine + IV saline vs block with saline }+ \\
\text { IV } 0.1 \mathrm{mg} / \mathrm{kg} \text {,orphine ( } 15 \text { pts/group) }\end{array}$ & Postsurg & $\begin{array}{l}\text { No diffs in pain scores or time to } 1 \text { st re- } \\
\text { quest for SQ codeine (median } \leq 25 \mathrm{~min} \\
\text { in both groups) in 24-hr study pd. }\end{array}$ \\
\hline $\begin{array}{l}\text { Gottschalk et } \\
\text { al [42] }\end{array}$ & Intracranl & Observ & $\begin{array}{l}\text { Scalp block (generallt } 0.5 \% \text { bupiv, } n=30 \text { vs } \\
\text { standard pratice (generally surg infiltration of } \\
\text { incision with } 0.25 \% \text { bupiv, } n=157 \text { ) }\end{array}$ & Preincis & $\begin{array}{l}\text { Reduced rest pain over } 1 \text { st } 2 \text { postop } \\
\text { days \& pain with movement om } 1 \text { st, not } \\
\text { 2nd, postop day }\end{array}$ \\
\hline $\begin{array}{l}\text { Honnma et al } \\
\text { [5] (in Japa- } \\
\text { ness) }\end{array}$ & $\begin{array}{l}\text { Supratent } \\
\text { (aneurysm } \\
\text { clipping) }\end{array}$ & RCT & $\begin{array}{l}\text { NSAID given preop, Scalp block (supraorb \& } \\
\text { supratrochl nerves) } \mathrm{w} / 0.25 \% \text { bupiv preinci- } \\
\text { sion }+ \text { incisional infiltration w/lidocaine } \\
\text { preincision }+ \text { incisional infiltration w/bupiv } \\
\text { postsurg vs surg site infitration w/lidocaine } \\
\text { preincision ( } 10 \text { pts/group) }\end{array}$ & $\begin{array}{l}\text { Preincis \& } \\
\text { Postsurg }\end{array}$ & $\begin{array}{l}\text { Pain scores, NSAID use } 6,12,24 \mathrm{hrs} \\
\text { postsurg and } 3,5,7,14 \text { days postsur- } \\
\text { gery less in intervention group (from } \\
\text { Abstract; see Chronic pain }\end{array}$ \\
\hline $\begin{array}{l}\text { Imaev et al } \\
{[63] \text { n(in Rus- }} \\
\text { sian) }\end{array}$ & Intracranl & $\mathrm{RCT}$ & $\begin{array}{l}5 \text { groups: 1) postop NSAIDs (control), 2) } \\
\text { postop NSAIDs (control), 3) preop \& postop } \\
\text { NSAIDs, 4) ropiv scalp block + infiltration, } \\
\text { 5) preop \& postop fentanyl. }\end{array}$ & Preincis & $\begin{array}{l}\text { Scalp block group had less pain in the } \\
\text { 54-hr observ pd vs } 2 \text { control groups } \\
\text { (from Abstract) }\end{array}$ \\
\hline $\begin{array}{l}\text { Law-Kaoune et } \\
\text { al [64] }\end{array}$ & Supratent & $\mathrm{RCT}$ & $\begin{array}{l}3 \text { groups: infiltration of } 20 \mathrm{~mL} \text { of } 1) \text { saline } \\
\text { (control, } n=40), 2) 0.375 \% \text { bupiv } / 1: 200 \mathrm{~K} \\
\text { epinephr }(n=20), 3) 0.75 \% \text { ropiv }(n=20)\end{array}$ & Postsurg & $\begin{array}{l}\text { Intervention groups showed opioid- } \\
\text { sparing effect in } 1 \text { st } 2 \text { hrs of } 16-\mathrm{hr} \\
\text { observation pd; no diffs in VAS }\end{array}$ \\
\hline $\begin{array}{l}\text { Nguyen et } \\
\text { al [6] }\end{array}$ & Supratent & $\mathrm{RCT}$ & $\begin{array}{l}\text { Scalp block: } 20 \mathrm{~mL} 0.75 \% \text { ropiv vs saline } \\
\text { controls (15/group) }\end{array}$ & Postsurg & $\begin{array}{l}\text { VAS lower in scalp block group in } 48 \text {; } \\
\text { no diffs in } 1 \text { st request or SQ codeine } \\
\text { use postop }\end{array}$ \\
\hline $\begin{array}{l}\text { Saringcarinkul } \\
\text { Intracranl \& } \\
\text { Boonsri [65] }\end{array}$ & Intracranl & RCT & $\begin{array}{l}\text { Infiltration: } 0.5 \% \text { bupiv/ } 1: 400 \mathrm{~K} \text { epinephr vs } \\
\text { saline/1:400K epinephr controls (25/group) }\end{array}$ & Postsurg & $\begin{array}{l}\text { Lower median pain score tended to be } \\
\text { in bupiv group in } 1 \text { st } 12 \mathrm{hrs} \text {; diff signifi- } \\
\text { cant only in } 1 \text { st hour }\end{array}$ \\
\hline \multicolumn{6}{|c|}{$\begin{array}{l}\mathrm{RCT}=\text { randimized controlled trial, remifent=remifentanil, } \mathrm{GA}=\text { general anethesia, postsurg=postsurgical, } 1 \mathrm{st} \text { request=firs request for pain medica- } \\
\text { tion, } \mathrm{SQ}=\text { subcutaneous, bupiv=bupivacaine, he=hour, } \mathrm{pt}=\text { patient, } \mathrm{pd}=\text { =period, epinephr=epinephrine, med=medication }(\mathrm{s}) \text {, observ=observation, } \\
\text { intracranl=intracranial, rpiv=ropivacaine, } \mathrm{IV}=\text { intravenous, preincis=preincisional, } \mathrm{n} / \mathrm{pts}=\text { number of patients, no diffs=no differences, min=minute, } \\
\mathrm{PACU}=\text { postanesthesia Care Unit, postop=postoperative, bilat=bilateral, surg=surgical, NSAID=nonsteroidal anti-inflammatory drugs, } \\
\text { preop=preoperative, supraorb=supraorbital, supratrochl=supratrochlear, VAS=visual analog scale, mos=months. } \\
\text { * "Intracranial" includes supratentorial (supratent) and infratentorial (infratent) procedures. }\end{array}$} \\
\hline
\end{tabular}




\section{Pada Penggunaan Obat Anestesi}

Penelitian di Thailand menunjukan bahwa prosedur pemasangan head pin pada kraniotomi adalah bagian paling nyeri, dengan kombinasi anestesi umum dan scalp block memberikan hasil pengurangan konsumsi opioid dan perubahan hemodinamik yang tidak bermakna dan segera dapat dinilai kondisi neurologis. ${ }^{2,14,15}$ Penelitian acak pada enam belas pasien membandingkan kelompok scalp block bupivacain 0,25\% kombinasi $50 \%$ nitro oksida $\left(\mathrm{N}_{2} \mathrm{O}\right)$ dengan kelompok anestesi umum berbasis isofluran. Apabila didapat peningkatan tekanan arteri rerata (MAP) lebih besar dari 20\% di atas batas awal akan mendapat tambahan obat anestesi natrium tiopental $2,5 \mathrm{mg} / \mathrm{kg}$ dan fentanil $2 \mathrm{ug} / \mathrm{kg}$ intra venus (i.v). Hasil penelitian ini menunjukan $25 \%$ pasien kelompok scalp block yang memerlukan tambahan obat anestesi IV, sedang pada kelompok anestesi umum $100 \%$ pasien memerlukan tambahan obat anestesi lebih banyak. ${ }^{2,15,16}$

\section{Pengaruh Scalp Block terhadap nyeri}

\section{Terhadap Nyeri Akut}

Pembedahan intrakranial yang mendapatkan scalp block memerlukan tambahan obat anestesi intravena yang lebih sedikit, teknik ini memberi analgesi terbaik selama belum terjadi manipulasi duramater. Kerusakan jaringan pada prosedur intrakranial merupakan pain generator pasca operasi sebagai pencetus nyeri dengan derajat sedang sampai berat dan derajat nyeri yang lebih berat pada prosedur infratentorial.

Kaitan dengan hal tersebut efek samping obat nyeri pasca operasi akan menimbulkan gejala yang menutupi gejala dari kenaikan tekanan intrakranial seperti sedasi, miosis, muntah, ataupun akibat kenaikan $\mathrm{CO}_{2}$ yang menyebabkan vasodilatasi, depresi pernafasan sebagai akibat penggunaan opioid. Penggunaan scalp block relevan dan realistis, menampilkan peran natural tanggapan terhadap nyeri setelah pembedahan intrakranial, serta menyingkirkan efek buruk penggunaan opioid. Beberapa penelitian menguji peran scalp block, penyuntikan anestesi lokal pada daerah operasi bilateral atau unilateral blok didapatkan hasil akan menurunkan derajat dan kejadian nyeri pasca operasi. ${ }^{14,15}$.
Pengaruh Scalp Block terhadap Nyeri Kronis Nyeri pascabedah dapat menetap dan menjadi kronis tidak terkecuali nyeri akibat pembedahan intrakranial. Penomena nyeri pascabedah yang terjadi pada fossa posterior merupakan hal yang umum terjadi dan menetap untuk waktu beberapa bulan, semakin memberat sesuai dengan perjalanan waktu. Pada operasi supra tentorial $56 \%$ pasien mengalami nyeri selama dua bulan pascaoperasi, $50 \%$ nya mengeluhkan sebagai nyeri neuropati. Dengan infiltrasi bupivakain $0,75 \%$ pada daerah sayatan saat penutupan kulit akan menurunkan kejadian nyeri pada dua bulan pascaoperasi dan hanya $8 \%$ yang mengeluhkan nyeri neuropati. Penelitian lain menunjukan keuntungan jangka panjang dari penggunaan scalp block dengan menurunnya nyeri dan menurunnya jumlah kebutuhan obat analgesi selama 14 hari pascaoperasi. ${ }^{16,17}$

\section{Simpulan}

Penggunaan scalp block utuk operasi intrakranial menunjukan hasil yang sangat efektif, dengan teknik yang sederhana dan aman untuk blok neuronal. Pemahaman anatomi dari persarafan area insisi operasi pada kulit kepala menjadi sangat penting dalam mencapai keberhasilan teknik tersebut. Scalp block diindikasi untuk menumpulkan pengaruh hemodinamik terhadap respon pembedahan serta menurunkan nyeri akut ataupun nyeri kronis pada pembedahan intrakranial-ekstrakranial, untuk hal tersebut diperlukan kombinasi teknik, pemahaman pasien serta perkembangan teknik terbaru. Namun demikian penggunaan ekstrakranial blok termasuk scalp block untuk menghilangkan nyeri dari duramater tidak optimal dan merupakan keterbatasan dari teknik ini dalam menangani nyeri pascaoperasi. Dengan demikian untuk prosedur yang menyebabkan tarikan, manipulasi, serta menyebabkan inflamasi duramater efektifitas scalp block akan sangat tergantung dengan penambahan analgesik lainnya.

\section{Daftar Pustaka}

1. Ames PR, Pollack GJ. Nerve blocks of 
the face. NYSORA Textbook of Regional Anesthesia and Acute Pain Management. https://www.nysora.com/techniques/headand-neck-blocks/nerve-blocks-face/

2. Guilfoyle MR, Helmy A, Duane D, Hutchinson PJ. Regional scalp block for postcraniotomy analgesia: a systematic review and meta analysis. Anesth Analg 2013; 116:1093

3. Tonković D. Regional anesthesia for neurosurgery. Acta Clin Croat. 2019; 58(Suppl 1): 48-52.

4. Potters JW, Klimek M. Local anesthetics for brain tumor resection: current perspectives. Journals Local and Regional Anesthesia 2017: 11.

5. Singh D. Thakur R. Rashmi N, Mangal V. Scalp block with bupivacaine and ropivacaine for attenuation of haemodynamic response to head pinning in neurosurgical patients an observational study. Indian Journal of Clinical Anaesthesia, January-March 2019;6(1):6-10

6. Morgan GE Jr, Mikhail MS, Murray MJ. Clinical Anesthesiology. 4th ed. New York, McGraw-Hill companies. 2006; 216-7.

7. Osborn I, Sobeo J. Scalp block during craniotomy: a classic technique revisited. J Neurosurg Anesthesiol 2010; 0(00).

8. Bisri DY, Bisri T. Awake craniotomy: pengalaman dengan dexmedetomidin. Jurnal Neuroanestesi Indonesia. 2016:4(3).

9. Hassan MH, Hassan WMNW, Kandasamy $\mathrm{R}, \mathrm{Eu}$ ChS. Unilateral complete ptosis after scalp block for awake craniotomy: A rare complication. J Neuroanaesthesiol Crit Care 2018;5:111-13.

10. Sargın M, Samancioğlu H, Uluer MS.
Transient facial nerve palsy after the scalp block for burr hole evacuation of subdural hematoma. Turk J Anaesthesiol Reanim 2018; 46: 238-40.

11. Tuchindatuchnp L, Somboonviboon W, Supbornsug K. Bupivacaine scalp nerve block: hemodynamic response during craniotomy, intraoperatif and post-operative analgesia. Asianbiomedicine. 2010;4(2):243251

12. Tonkovic D, Stambolija V, Lozic M, Martinovic P, Pavlovic DB, Sekulic A, Baronica R, Peric M. Scalp block for hemodynamic stability during neurosurgery. Period boil. 2015;117(2).

13. Guilfoyle MR, Helmy A, Duane D, Peter J, Hutchinson A. Regional scalp block for postcraniotomy analgesia: systematic review and meta-analysis. Neuroscience in Anesthesiology and Perioperatif Medicine. 2013;116(5):1093-110.

14. Nguyan A, Girard F. Girard DJ, Caron JL. Scalp nerve blocks decrease the severity of pain after craniotomy. Anesth Analg 2001; 93(5):1272-6.

15. Haldar R, Kaushal A, Gupta D, Srivastava S, dan Singh PK. Pain following craniotomy: reassessment of the available options. Bio Med Research International. 2015, Article ID 509164, 8 pages, http://dx.doi. org/10.1155/2015/509164

16. Lovely TJ. The treatment of chronic incisional pain and headache after retromastoid craniectomy. Surg Neurol Int.2012;3(92)

17. Bala I, Gupta B, Bhardway N, Ghai B, Khosla VK. Scalp block on post operative pain relief in craniotomy patients. Anaesth Intensive Care 2006;34: 224-27. 